\title{
ESTIMATION OF WATER TURNOVER RATES OF CAPTIVE WEST INDIAN MANATEES (TRICHECHUS MANATUS) HELD IN FRESH AND SALT WATER
}

\author{
RUDY M. ORTIZ ${ }^{1, *}$, GRAHAM A. J. WORTHY ${ }^{1}$ AND FLOYD M. BYERS ${ }^{2}$ \\ ${ }^{1}$ Physiological Ecology and Bioenergetics Research Laboratory, Texas A\&M University at Galveston, Galveston, TX \\ 77551, USA and 2 Department of Animal Science, Texas A\&M University, College Station, TX 77843, USA \\ *Present address: Earth and Marine Science A316, Department of Biology, University of California at Santa Cruz, Santa Cruz, CA 95064, USA \\ (e-mail: rortiz@mail.arc.nasa.gov)
}

Accepted 26 October; published on WWW 7 December 1998

\begin{abstract}
The ability of West Indian manatees (Trichechus manatus) to move between fresh and salt water raises the question of whether manatees drink salt water. Water turnover rates were estimated in captive West Indian manatees using the deuterium oxide dilution technique. Rates were quantified in animals using four experimental treatments: (1) held in fresh water and fed lettuce $(N=4)$, (2) held in salt water and fed lettuce $(N=2)$, (3) acutely exposed to salt water and fed lettuce $(N=4)$, and (4) chronically exposed to salt water with limited access to fresh water and fed sea grass $(N=5)$. Animals held in fresh water had the highest turnover rates $\left(145 \pm 12 \mathrm{ml} \mathrm{kg}^{-1} \mathrm{day}^{-1}\right)$ (mean \pm S.E.M.). Animals acutely exposed to salt water decreased their turnover rate significantly when moved into salt water (from $124 \pm 15$ to $65 \pm 15 \mathrm{ml} \mathrm{kg}^{-1} \mathrm{day}^{-1}$ ) and
\end{abstract}

Summary subsequently increased their turnover rate upon re-entry to fresh water $\left(146 \pm 19 \mathrm{ml} \mathrm{kg}^{-1}\right.$ day $\left.^{-1}\right)$. Manatees chronically exposed to salt water had significantly lower turnover rates $\left(21 \pm 3 \mathrm{ml} \mathrm{kg}^{-1} \mathrm{day}^{-1}\right)$ compared with animals held in salt water and fed lettuce $\left(45 \pm 3 \mathrm{ml} \mathrm{kg}^{-1} \mathrm{day}^{-1}\right)$. Manatees chronically exposed to salt water and fed sea grass had very low turnover rates compared with manatees held in salt water and fed lettuce, which is consistent with a lack of mariposia. Manatees in fresh water drank large volumes of water, which may make them susceptible to hyponatremia if access to a source of $\mathrm{Na}^{+}$is not provided.

Key words: manatee, Trichechus manatus, water turnover, salt water, fresh water, drinking, mariposia.

\section{Introduction}

The habitat range of sirenians extends from strictly fresh water (Amazonian manatee, Trichechus inunguis) to strictly marine (dugong, Dugong dugon). Among sirenians, West Indian manatees (Trichechus manatus) appear to be the most flexible species since they inhabit both freshwater and marine environments. This flexibility suggests that drinking both fresh and salt water may be common in this species. However, drinking and its contribution to water turnover have yet to be examined in any sirenian.

Although this species is most frequently associated with fresh water, the presence of West Indian manatees in marine areas for prolonged periods is intriguing (Hill and Reynolds, 1989). Individual animals may occasionally spend prolonged periods at sea, as suggested by the amount of barnacle growth present on their bodies (Husar, 1977). Also, the observation of two West Indian manatees near the Dry Tortugas Islands, Florida, USA (Reynolds and Ferguson, 1984), a location not normally considered to be part of the range of the species and far from fresh water, also provides evidence of their ability to tolerate osmotic pressures induced by marine habitats (Maluf, 1989). However, West Indian manatees are known to migrate over great distances from marine habitats to freshwater rivers and to congregate around freshwater effluents (Rathbun et al. 1990). Movement from marine habitats to areas of fresh water could suggest that manatees consuming marine vegetation require fresh water. Such observations raise the question of whether West Indian manatees require regular access to fresh water for osmoregulation or whether they meet their water requirements through other means.

The distribution patterns of sirenians suggest that they may possess a range of physiological capabilities relating to water balance and osmoregulation. Dugongs and manatees possess kidneys which, on the basis of their anatomy, should theoretically enable them to deal with a marine environment for prolonged periods (Batrawi, 1957; Hill and Reynolds, 1989; Maluf, 1989). Irvine et al. (1980) suggested that West Indian manatees were capable of drinking salt water since urine osmolality varied with salinity. Also, freshwater manatees acutely exposed to salt water exhibited an increase in urine $\mathrm{Na}^{+}$concentration and osmolality (Ortiz et al., 1998). These data suggest that West Indian manatees may have the renal capability to meet their water requirements through mariposia. Mariposia has been reported in marine 
mammals (Telfer et al., 1970; Gentry, 1981; Hui, 1981; Costa, 1982), but has not been described in sirenians.

In the present study, water turnover rates were measured in West Indian manatees held in fresh and salt water and fed either lettuce or sea grass. Water turnover rate and total body water pool size were estimated using deuterium oxide $\left(\mathrm{D}_{2} \mathrm{O}\right)$ dilution. Isotopic methods have been used extensively to estimate the size of the total body water pool and water turnover rates, and have been validated for a variety of vertebrates (e.g. Foy and Schnieden, 1960; Lifson and McClintock, 1966; Nagy, 1989).

\section{Materials and methods}

Deuterium oxide dilution trials were conducted on captive West Indian manatees (Trichechus manatus) (L.) held under four experimental treatments: (1) in fresh water and fed lettuce, (2) in salt water and fed lettuce, (3) acutely exposed to salt water and fed lettuce, and (4) chronically exposed to salt water with limited access to fresh water and fed sea grass.

Manatees were weighed to $\pm 0.1 \mathrm{~kg}$ in a sling using a hanging load cell prior to each trial. Blood samples were taken from the venous plexus in the flipper. An initial blood sample was taken prior to administration of the isotope to determine background levels of $\mathrm{D}_{2} \mathrm{O}$. Animals received a dose of $1-2 \mathrm{~g} \mathrm{D}_{2} \mathrm{O} \mathrm{kg}^{-1}$ body mass $\left(\mathrm{D}_{2} \mathrm{O}, 99.9\right.$ atom $\%$, Isotec, Inc., Miamisburg, OH, USA) via $60 \mathrm{ml}$ syringes, pre-weighed to the nearest $0.1 \mathrm{~g}$. To ensure complete administration of $\mathrm{D}_{2} \mathrm{O}$, the oral intubation tube was flushed with approximately $120 \mathrm{ml}$ of tap water. After administration of isotope, subsequent blood samples were obtained (details of the sampling regimes are given below).

Blood samples were placed into $10 \mathrm{ml}$ scintillation vials (Kimble Glass, Vineland, NJ, USA) and frozen at $-70^{\circ} \mathrm{C}$ for later analysis of $\mathrm{D}_{2} \mathrm{O}$. Water was lyophilized from whole blood using a freeze trap method (Byers, 1979), and $\mathrm{D}_{2} \mathrm{O}$ was measured using an infrared analyzer (model 5651, Wilks Scientific, Foxboro/Wilks, Inc., South Norwalk, CT, USA) (Byers, 1979).

The instantaneous dilution space of the isotope was defined as the $y$-intercept $\left(T_{0}\right)$ from a three-point regression of $\log _{\mathrm{e}}\left[\mathrm{D}_{2} \mathrm{O}\right]$ versus time (days) (Byers and Schelling, 1986). Isotopic dilution space (IDS, in l) was calculated as:

$$
\mathrm{IDS}=\frac{D}{1.105\left[T_{0}\right]},
$$

where $D$ is the administered dose of $\mathrm{D}_{2} \mathrm{O}(\mathrm{mg}), 1.105$ is the correction for the density of $\mathrm{D}_{2} \mathrm{O}$ versus $\mathrm{H}_{2} \mathrm{O}$, and $\left[T_{0}\right]$ is the concentration of $\mathrm{D}_{2} \mathrm{O}$ at time zero $\left(\mathrm{mll}^{-1}\right)$ (Byers and Schelling, 1986). In the present study, IDS was used as an estimate of total body water. Water turnover rate $\left(\mathrm{lday}^{-1}\right)$ was calculated as the product of total body water and the slope of the three-point regression. In cases where animals lost body mass, turnover rate was estimated using the equations presented by Nagy and Costa (1980) that account for changes in the size of the water pool.
Samples of the animal's food were desiccated to determine their hydration state, which was used to estimate the contribution of dietary water to turnover rates. Records were kept of the amount of food placed in the tank containing the animals. If none of the food was recovered after each feeding period, it was assumed that all the food had been eaten. In cases where food still remanied after a feeding period, it was removed from the water, shaken (to remove as much of the external moisture as possible) and weighed. Dietary water intake in each experimental treatment was estimated as the product of the amount of food consumed and its hydration value. Food intake was averaged for all animals in a tank and corrected for the total body mass of the study subjects in a particular treatment (i.e. daily total dietary water divided by total biomass in a treatment, resulting in a value of $\mathrm{ml} \mathrm{H}_{2} \mathrm{O} \mathrm{kg}^{-1}$ body mass day ${ }^{-1}$ ). Observations to quantify an individual's daily consumption were not possible; therefore, the dietary water values presented estimate the greatest potential contribution to turnover rate. During steady-state conditions (animals not losing body mass), metabolic water was calculated on the basis of half the basal metabolic rate predicted by Kleiber (Gallivan and Best, 1986). Metabolic rate was converted to metabolic water production assuming $0.12 \mathrm{ml} \mathrm{H}_{2} \mathrm{O} \mathrm{kcal}^{-1}$ based on a respiratory quotient (RQ) of 0.76 (Worthy, 1990). In the cases where animals did lose body mass, metabolic water was calculated as the amount of water produced from the oxidation of body fat assuming $1.07 \mathrm{~g} \mathrm{H}_{2} \mathrm{O} \mathrm{g}^{-1}$ fat oxidized (Worthy, 1990).

Analysis of variance was used to compare mean ( \pm S.E.M.) absolute and mass-specific water turnover rates. For water turnover rates determined in the acute and chronic saltwater experiments, means for each phase of the respective experiments were compared by analysis of variance adjusted for repeated measures. Fisher's PLSD test was applied post$h o c$ if a difference $(P<0.05)$ was observed. Statistics were performed using Statview for the Macintosh software (Abacus Concepts, Inc., 1992).

\section{Fresh water}

Two turnover trials (October 1992 and January 1993) were conducted on two manatees (1.5 and 2 years old; 151.5 and $223.3 \mathrm{~kg}$ ) which were fed lettuce and held at Sea World of Florida, Orlando, FL, USA. One trial (October 1993) was conducted on two males (1.2 and 9 years old; 175.9 and $412 \mathrm{~kg}$ ) which were also fed lettuce, but were held at Lowry Park Zoo, Tampa, FL, USA. Following administration of isotope, blood samples were taken at $12 \mathrm{~h}, 2$ and 5 days in all trials for all animals in this group. In none of the animals did body mass change over the trial period; therefore, water turnover rates were calculated from a constant pool size. For statistical purposes, mean values were determined for the two trials for each of the two Sea World animals, and these values were then used in determining the mean value for this group $(N=4)$.

\section{Salt water}

Two manatees were studied which had been permanently 
held in salt water (approximately 34\%o) and provided access to fresh water either from a hose or from a hydrated diet. One of the manatees was held at EPCOT's Living Seas and ranged in age from 11 to 18 months $(273.6-403.2 \mathrm{~kg}$ ) during his three water turnover trials conducted in August and November 1992 and March 1993. His normal diet of lettuce was not changed during these trials. In March 1995, one turnover trial was conducted on the second manatee ( 8 years old; $375 \mathrm{~kg}$ ), which was held at Centro Peixe-Boi/IBAMA in Brazil. She was maintained on her regular diet of mixed vegetables (lettuce, beets, carrots and cabbage) supplemented with freshly cut sea grass (Halodule spp.) and had access to fresh water from a hose for approximately $2 \mathrm{hday}^{-1}$. After administration of isotope, blood samples were taken at $12 \mathrm{~h}, 2$ or 3 days, and 5 days for both animals. In neither of these animals did body mass change during the course of their trial period; therefore, water turnover rates were calculated from a constant pool size. For statistical purposes, the EPCOT animal's three turnover rates were averaged, and this value was used to determine the mean value for the group $(N=2)$.

\section{Acute saltwater exposure}

Four manatees (1-4 years old; $170.5-400 \mathrm{~kg}$ ) which had been permanently held in fresh water at Sea World of Florida were acutely exposed to salt water without changing their diet of romaine lettuce. During the initial freshwater phase, blood was taken from the manatees at $12 \mathrm{~h}$, and 2 and 5 days following administration of isotope. The water in the tank was then switched to salt water (32-35\%o), and blood was taken from the manatees after 2 and 5 days of exposure. After reintroduction to fresh water, blood samples were taken after 2 and 5 days. Over the course of their trial period, the body mass of none of the animals changed; therefore, turnover rate was calculated from a constant pool size.

\section{Chronic saltwater exposure}

Five manatees (3-8 years old; $175-420 \mathrm{~kg}$ ) which had been permanently held in salt water $(34 \%$ ) at Centro PeixeBoi/IBAMA in Brazil were fed freshly cut sea grass during a
19 day turnover trial. The trial consisted of an initial 5 day period during which the animals had access to fresh water from a hose, followed by a 9 day freshwater deprivation phase, and concluded with a 5 day period during which they had access to fresh water again. Following the pre-dose blood sample, further samples during the initial phase were taken at $12 \mathrm{~h}, 3$ and 5 days. During the 9 day water deprivation phase, blood was taken from the animals at 2, 5 and 9 days. Blood was again taken from the aninals after 2 and 5 days during the final period when fresh water was again made available. During phases when fresh water was made available, manatees were provided with fresh water from a hose for approximately $2 \mathrm{hday}^{-1}$. Animals were seen with their mouths open underneath the flow of water. When an animal's body mass changed, turnover rates were determined using the equations described in Nagy and Costa (1980) for non-steady-state water pool sizes and assuming that the changes in total body water pool sizes were proportional to their changes in body mass. When body mass did not change, turnover rate was calculated using a constant pool size.

\section{Results}

Absolute and mass-specific water turnover rates for each treatment are summarized in Table 1. The water contents of lettuce and sea grass were determined to be approximately $92 \%$ and $57 \%$, respectively. The water contents of the lettuce, cabbage, carrots and beets fed to the manatee in salt water in Brazil were $94 \%, 92 \%, 90 \%$ and $88 \%$, respectively.

\section{Fresh water}

The four manatees continued to eat lettuce regularly throughout the course of their water turnover trials. Absolute and mass-specific turnover rates did not differ significantly from those of animals during the freshwater phases of the acute salt water experiment (Table 1). Absolute water turnover rate for the four animals ranged between 23.9 and 47.81 day $^{-1}$, with the largest manatee $(412 \mathrm{~kg})$ consuming the greatest volume of water and having the largest total body water pool. Total body water pool sizes ranged from 105.8 to 267.61 .

Table 1. Estimated water turnover rates for manatees undergoing different treatments

\begin{tabular}{llccc}
\hline Treatment & $N$ & Diet & Water turnover $\left(1\right.$ day $\left.^{-1}\right)$ & ${\text { Water turnover }\left(\mathrm{ml} \mathrm{kg}^{-1} \mathrm{day}^{-1}\right)}$ \\
\hline Fresh water & 4 & Lettuce & $32.8 \pm 5.1^{\mathrm{a}}$ & $145 \pm 12^{\mathrm{a}}$ \\
$\quad$ Salt water & 2 & Lettuce & $15.5 \pm 1.5^{\mathrm{b}}$ & $45 \pm 3^{\mathrm{b}}$ \\
$\quad$ Acute saltwater exposure & & & & $124 \pm 15^{\mathrm{a}}$ \\
$\quad$ Initial freshwater phase & 4 & Lettuce & $34.5 \pm 4.7^{\mathrm{a}}$ & $65 \pm 15^{\mathrm{b}}$ \\
$\quad$ Saltwater phase & 4 & Lettuce & $19.2 \pm 6.6^{\mathrm{b}}$ & $146 \pm 19^{\mathrm{a}}$ \\
$\quad$ Re-entry to freshwater phase & 4 & Lettuce & $41.1 \pm 5.7^{\mathrm{a}}$ & $21 \pm 3^{\mathrm{c}}$ \\
$\quad$ Chronic saltwater exposure & & & & $17 \pm 2^{\mathrm{c}}$ \\
$\quad$ Initial phase with fresh water available & 5 & Sea grass & $7.2 \pm 0.8^{\mathrm{c}}$ & $23 \pm 8^{\mathrm{c}}$
\end{tabular}

See text for details of treatments.

Values with different superscripts in each column correspond to significantly different $(P<0.05)$ means \pm S.E.M. 


\section{Salt water}

Absolute turnover rate was approximately 50\% lower and mass-specific turnover rate was approximately $70 \%$ lower than those for animals in fresh water (Table 1). Total body water pool sizes for this group ranged between 123.0 and 194.51.

\section{Acute saltwater exposure}

Total body water pool sizes ranged between 106.2 and 217.71 for this group. Animals exhibited a significant decrease in absolute and mass-specific water turnover rate when switched to salt water and a significant increase upon returning to fresh water (Table 1). Absolute and mass-specific turnover rates during the saltwater phase were not significantly different from that for animals held in salt water on a lettuce diet (Table 1).

\section{Chronic saltwater exposure}

During the initial phase of this experiment, all five animals reduced their sea grass intake, resulting in a loss in their initial body mass of between 1.5 and $17.1 \%$. During the freshwater deprivation phase, two animals had further mass losses of $1.0 \%$ and $3.0 \%$, while two animals had mass increases of $1.4 \%$ and $6.1 \%$. Mass did not alter over the final phase of the study. Initial total body water pool sizes ranged between 102.3 and 256.31. The decrease in absolute water turnover rate exhibited when animals were deprived of fresh water and the subsequent increase when fresh water was again made available were significant (Table 1). On average, these turnover rates were still two- to fourfold lower than that for manatees in salt water on a lettuce diet. Mass-specific turnover rates were not significantly different during any of the three phases; however, these turnover rates were significantly lower than that for animals held in salt water on a lettuce diet (Table 1).

\section{Discussion}

Although mariposia has been described in other marine mammals (Gentry, 1981; Hui, 1981; Costa, 1982), the results of the present study indicate that manatees do not engage in this practice. When a water budget (Table 2) was constructed, turnover rates (influx) for manatees held in salt water could be completely accounted for by the contribution of dietary and metabolic water, with the exception of animals that were chronically exposed to salt water and deprived of fresh water. The $5 \mathrm{ml} \mathrm{H}_{2} \mathrm{O} \mathrm{kg}^{-1}$ day $^{-1}$ that could not be accounted for in this group was probably the result of incidental ingestion during feeding. This relatively small turnover rate is similar to the calculated mean $\left(4 \mathrm{ml} \mathrm{H}_{2} \mathrm{O} \mathrm{kg}^{-1} \mathrm{day}^{-1}\right)$ for ingested sea water in captive harbor seals (Phoca vitulina), which the authors concluded to be incidental to feeding under water (similar to manatees) rather than to deliberate consumption (Depocas et al., 1971). Also, this mass-specific turnover rate was approximately 2.5- to fourfold lower than that for saltwater manatees fed lettuce, further suggesting an absence of mariposia.

Only animals that were chronically exposed to salt water demonstrated a reduction in body mass. An RQ of 0.71 has previously been reported for fasting Amazonian manatees, indicating that fat was the primary substrate of metabolism (Gallivan and Best, 1986). On the basis of this previous study, mass loss in the present study was assumed to be due primarily to the oxidation of fat. If so, water turnover rates during the initial phase could be accounted for by water derived from fat oxidation (Table 2). This suggests that the production of water from the oxidation of fat could be a source of water for manatees during periods of reduced food consumption (or fasting). Manatees have large visceral and subcutaneous fat stores, which could allow them to oxidize large amounts of fat

Table 2. Calculated water budget for manatees held under varying conditions

\begin{tabular}{|c|c|c|c|c|c|}
\hline Treatment & $N$ & $\begin{array}{c}\text { Influx } \\
\left(\mathrm{ml} \mathrm{kg}^{-1} \mathrm{day}^{-1}\right)\end{array}$ & $\begin{array}{c}\text { Dietary } \\
\left(\mathrm{ml} \mathrm{kg}^{-1} \mathrm{day}^{-1}\right)\end{array}$ & $\begin{array}{c}\text { Metabolic } \\
\left(\mathrm{ml} \mathrm{kg}^{-1} \mathrm{day}^{-1}\right)\end{array}$ & $\begin{array}{l}\text { Unaccounted } \\
\left(\mathrm{ml} \mathrm{kg}^{-1} \mathrm{day}^{-1}\right)\end{array}$ \\
\hline Fresh water & 4 & 145 & 103 & 1 & 41 \\
\hline \multicolumn{6}{|l|}{ Acute saltwater exposure } \\
\hline Initial freshwater phase & 4 & 124 & 102 & 1 & 21 \\
\hline Saltwater phase & 4 & 65 & 90 & 1 & 0 \\
\hline Initial phase with fresh water available & 5 & 21 & 2 & 24 & 0 \\
\hline Freshwater deprivation phase & 5 & 17 & 10 & $2 *$ & 5 \\
\hline Final phase with fresh water available & 5 & 23 & 7 & 1 & 15 \\
\hline
\end{tabular}

Dietary water refers to the potential contribution of preformed water from the diet to water turnover rate.

Metabolic water was calculated as half of that predicted by Kleiber (Gallivan and Best, 1986) or from the oxidation of body fat in the cases when animals lost body mass.

Unaccounted water was calculated as the difference between water influx and the sum of dietary and metabolic water.

Negative unaccounted water values are reported as zero.

*Value represents the mean metabolic water for three animals that did not lose body mass (half the value predicted by Kleiber) and two that lost body mass (water from fat oxidation).

Values are means. 
as a source of water. The production of water from fat oxidation is not uncommon in a variety of mammals (Ortiz et al., 1978). The oxidation of these fat stores may help explain the presence of manatees in marine habitats for extended periods (Husar, 1977; Reynolds and Ferguson, 1984).

Diet was also an important factor in the turnover rate of the animals. Manatees in salt water on a lettuce diet had higher turnover rates than animals in salt water fed sea grass. This suggests that lettuce was a significant contributor to turnover rate and a significant source of water to captive saltwater manatees. The observation that captive animals in salt water continued to consume lettuce without losing weight while some of the animals that were switched from their normal diet of terrestrial vegetables to sea grass lost weight suggests a preference of captive animals for lettuce which may have significant implications with regard to the husbandry of this endangered species.

The higher turnover rate for animals in fresh water, compared with that for animals in salt water, on a lettuce diet provides evidence that consumption of fresh water can occur and can contribute significantly to turnover rates. This suggests that animals feeding normally have the capacity to consume large amounts of fresh water (Table 2). The larger manatees held in fresh water had turnover rates comparable with those of terrestrial herbivores (beef cows, 429-472 kg), which have been shown to drink as much as 111 day $^{-1}$ of water with turnover rates ranging between 50 and $114 \mathrm{ml} \mathrm{kg}^{-1} \mathrm{day}^{-1}$ (Degen and Young, 1990). For captive freshwater animals on a lettuce diet, which has a naturally low $\mathrm{Na}^{+}$content, the possibility of hyponatremia exists. Captive freshwater manatees were reported to exhibit plasma $\mathrm{Na}^{+}$concentrations that were significantly lower than those of wild freshwater animals, suggesting that captive animals may be susceptible to hyponatremia (Ortiz et al., 1998). If this is the case, manatees in freshwater habitats may require exposure to marine environments to help maintain their plasma $\mathrm{Na}^{+}$concentration.

In summary, the present study represents the first attempt to estimate water turnover rates, and the possible significance of drinking, in any of the sirenians. Animals in salt water, regardless of diet, had significantly lower turnover rates than animals in fresh water. Moreover, manatees in salt water and fed sea grass exhibited significantly lower turnover rates than manatees in salt water and fed lettuce, demonstrating the contribution of a hydrated diet such as lettuce to the water turnover rate of animals in salt water. The initial water turnover rates for animals chronically exposed to salt water and fed sea grass could be accounted for by the water produced from the oxidation of fat, suggesting that manatees may utilize body fat, possibly visceral fat, as a 'water storage depot', as do other mammals. The water not accounted for during the deprivation phase in this group was probably the result of incidental ingestion during feeding, which is similar to that reported for harbor seals. The high water turnover rate observed in manatees held in fresh water suggests that these animals are capable of drinking large amounts of water, as are terrestrial herbivores. However, previous evidence (Ortiz et al., 1998) suggests that this high turnover rate may result in hyponatremia, a situation that can be avoided in the wild by feeding in saline environments, but may be a problem in some captive settings.

This research was conducted in partial fulfilment of the requirements for the degree of Master of Science for R.M.O. This study was funded by Save the Manatee Club, Sea World, EPCOT's Living Seas, Florida Department of Environmental Protection. We thank Sea World of Florida, EPCOT's Living Seas, Lowry Park Zoo, Tampa, Florida, and Centro PeixeBoi/IBAMA, Brazil, for allowing us to conduct our research at their facilities. We also thank the staff from each facility for their assistance in handling the animals and collecting data, and T. Christopher, T. Miculka and M. Reimers from Texas A\&M University for their assistance throughout the study. We are grateful for the constructive comments made by Drs Dan Costa and Dan Crocker, which improved the final version of this manuscript. This research was authorized under USFWS permit 766146 to G.A.J.W.

\section{References}

Abacus Concepts. (1992). StatView for the Macintosh. Berkeley, CA: Abacus Concepts, Inc.

Batrawi, A. (1957). The structure of the dugong kidney. Publ. Mar. Biol. Station, Al Ghardaqa, Egypt 9, 51-68.

Byers, F. M. (1979). Extraction and measurement of deuterium oxide at tracer levels in biological fluids. Analyt. Biochem. 98, 208-213.

Byers, F. M. and Schelling, G. T. (1986). Evaluation of deuterium oxide dilution systems for estimating body composition of beef cattle. Beef Cattle Res. Texas PR-4473,

Costa, D. P. (1982). Energy, nitrogen, electrolyte flux and sea water drinking in the sea otter Enhydra lutris. Physiol. Zool. 55, 35-44.

Degen, A. A. and Young, B. A. (1990). The performance of pregnant beef cows relying on snow as a water source. Can. J. Anim. Sci. 70, 507-515.

Depocas, F., Hart, J. and Fisher, H. D. (1971). Seawater drinking and water flux in starved and fed harbor seals, Phoca vitulina. Can. J. Physiol. Pharmac. 49, 53-62.

Foy, J. M. and Schnieden, H. (1960). Estimation of total body water (virtual tritium space) in the rat, cat, rabbit, guinea pig and man and of the biological half life in man. J. Physiol., Lond. 154, 169-176.

Gallivan, G. J. and Best, R. C. (1986). The influence of feeding and fasting on the metabolic rate and ventilation of the Amazonian manatee (Trichechus inunguis). Physiol. Zool. 59, 552-557.

Gentry, R. L. (1981). Seawater drinking in eared seals. Comp. Biochem. Physiol. 8A, 81-86.

Hill, D. A. and Reynolds, J. E. (1989). Gross and microscopic anatomy of the kidney of the West Indian manatee, Trichechus manatus (Mammalia: Sirenia). Acta Anat. 135, 53-56.

Hui, C. (1981). Seawater consumption and water flux in the common dolphin Delphinus delphis. Physiol. Zool. 54, 430-440.

Husar, S. L. (1977). The West Indian manatee (Trichechus manatus). US Dept Int., Fish Wildl. Serv., Wildl. Res. Rep. 7.

Irvine, A. B., Neal, R. C., Cardeilhac, R. T., Popp, J. A., Whiter, F. H. and Jenkins, R. C. (1980). Clinical observations on captive and free-ranging West Indian manatees, Trichechus manatus. Aquat. Mammal. 8, 2-10. 
Lifson, N. and McClintock, R. (1966). Theory of use of the turnover rates of body water for measuring energy and material balance. $J$. Theor. Biol. 12, 46-74.

Maluf, N. S. R. (1989). Renal anatomy of the manatee, Trichechus manatus (Linnaeus). Am. J. Anat. 184, 269-286.

Nagy, K. A. (1989). Doubly-labeled water studies of vertebrate physiological ecology. In Stable Isotopes in Ecological Research (ed. P. W. Rundel, J. R. Ehleringer and K. A. Nagy), pp. 270-287. New York: Springer-Verlag.

Nagy, K. A. and Costa, D. P. (1980). Water flux in animals: analysis of potential errors in the tritiated water method. Am. J. Physiol. 238, R454-R465.

Ortiz, C. L., Costa, D. and Le Boeuf, B. J. (1978). Water and energy flux in elephant seal pups fasting under natural conditions. Physiol. Zool. 51, 166-178.
Ortiz, R. M., Worthy, G. A. J. and MacKenzie, D. S. (1998). Osmoregulation in wild and captive West Indian manatees (Trichechus manatus). Physiol. Zool. 71, 449-457.

Rathbun, G., Reid, J. P. and Carowan, G. (1990). Distribution and movement patterns of manatees (Trichechus manatus) in Northwestern Peninsular Florida. Fl. Mar. Res. Publ. 48.

Reynolds, J. E. and Ferguson, J. C. (1984). Implications of the presence of manatees (Trichechus manatus) near the Dry Tortugas Islands, Florida, USA. Fl. Sci. 47, 187-189.

Telfer, N., Cornell, L. H. and Prescott, J. H. (1970). Do dolphins drink water? J. Am. Vet. Med. Ass. 157, 555-558.

Worthy, G. A. J. (1990). Nutritional energetics of marine mammals. In CRC Handbook of Marine Mammal Medicine: Health, Disease and Rehabilitation (ed. L. A. Dierauf), pp. 489-520. Boston: CRC Press. 